\title{
Development and characterization of a soymilk Kefir-based functional beverage
}

\author{
Camilla Fernanda Godinho da SILVA ${ }^{1}$, Ferlando Lima SANTOS ${ }^{1}$, Ligia Regina Radomille de SANTANA ${ }^{2 *}$, \\ Mariangela Vieira Lopes SILVA², Taiana de Araujo CONCEIÇÃO ${ }^{1}$
}

\begin{abstract}
Kefir is a fermented beverage that deserves special attention, since it has probiotic activity and unique sensory, nutritional, and therapeutic properties. Given that both kefir and soymilk are beneficial to human health, this study aimed to assess the physicochemical characteristics and acceptability of soymilk Kefir-based functional beverages (SKB) properly inoculated with lactobacilli strain after $16 \mathrm{~h}$ of incubation at $37^{\circ} \mathrm{C}$. It was monitored lactobacilli cell viability, yeasts count, $\mathrm{pH}$, titratable acidity, lipids, proteins, ash, total solid, carbohydrates, caloric values and acceptability of the products. Additionally was conducted a shelf-life study of SKB added of peach-flavor. The lactobacilli cell count ranged from 7.0 to $8.0 \log _{10} \mathrm{CFUmL}^{-1}$ and $\mathrm{pH}$ values from 4.5 to 4.6. SKB samples with higher soymilk kefir percent presented higher lactobacilli cell count and lower lipid, ash, total solid, carbohydrate and caloric value. Results showed similar preferential rates for the SKB up to 30\% of added soymilk kefir. The functional peach-flavored beverage presented appropriate $\mathrm{pH}$ value (4.3) and high viable cells count $\left(7.0 \log _{10} \mathrm{CFUmL}^{-1}\right)$ up to the $28^{\text {th }}$ day of cold storage, showed high acceptability $(94.5 \%)$ and positive purchase intention ( $\left.83.4 \%\right)$ among consumers.
\end{abstract}

Keywords: fermented food; soybean; probiotic; consumer; shelf-life.

Practical Application: To obtain knowledge about soymilk Kefir-based functional beverage, an innovative product and great sensory characteristics, using both kefir and soymilk, for technological use in the food industry. Besides, its consumption should be recommended, especially among the low-income population with little access to products with high nutritional value and health benefits.

\section{Introduction}

Healthy food with functional properties is an excellent choice to improve quality of life and prevent diseases (Saad et al., 2013). Probiotic foods and products containing prebiotics are categorized as functional food, defined as any food or food ingredient that may provide a healthy benefit beyond that of the traditional nutrients they contain (Falk, 2004). The term probiotics refers to live microbial cultures, which, when administered to humans or animals (in the form of dehydrated cells or fermented products), positively affect the host's health status by improving the properties of the original microbiota. The prophylactic and therapeutic effects of these micro-organisms have been reported in various studies: balance of the intestinal microbiota; increase of lactose tolerance and ingestion; reduction of cholesterol levels; synthesis of B complex vitamins; increase of the absorption of calcium; modulation of the immune system (Saad et al., 2013). In addition, the use of fructo-oligosaccharides (FOS) has attracted special attention because of their prebiotic properties and their sweet taste, very similar to that of sucrose (Al-Sheraji et al., 2013).

The demand for probiotic functional foods is growing rapidly due to the increased awareness on these products value. Thus, dairy products fermented with lactic acid bacteria, such as Bifidobacterium and Lactobacillus strains, sugar fortified (with fructo-oligosaccharides or inulin), have emerged on the food market in the last decade. The global market for functional foods and beverages has grown from US $\$ 33$ billion in 2000 to US $\$ 129$ billion in 2015 and it is expected reach US $\$ 255$ billion by 2024 (Research \& Markets, 2017), accounting for 5\% of the overall food market, and the probiotic foods comprise $60 \%$ to $70 \%$ of the total functional food market (Granato et al., 2010). Although official statistical data are not yet available, the market for foods containing probiotic cultures is increasing in Brazil. Dairy products (bio-yogurts, fermented milks, cheeses, lactic beverages) are currently the main representatives, and represented US $\$ 10$ billion in 2011. It is estimated that this category will reach $20 \%$ of food and beverages national market by 2020 (Sloan, 2012).

In this context of functional food is soy, a grain rich in proteins, vitamins, minerals, polyunsaturated fatty acids, fibers and fructo-oligosaccharides with prebiotic potential as raffinose and stachyose. It also contains others compounds with proven health benefits such as saponins, lecithins and isoflavones (Silva et al., 2009). Consumer interest for soybean-based food has increased in recent years; however, sensory characteristics such as the undesirable "raw beans" flavor and particular dietary habits are factors that still hinder the inclusion of soybean in usual diet. The acceptance of soy products may increase with association of additives or other ingredients as fruit pulp, others vegetable extracts, and flavoring substances, which was 
proven an excellent choice to produce a mild taste and to obtain soybean-based products with adequate sensory properties, increasing its added value and encouraging its consumption, while providing health benefits (Jaekel et al., 2010). The fermentation using probiotic lactic culture is a technological alternative to the transformation of soy extract, which is an appropriate substrate to the growth and activity of lactic bacteria due to its content of fructo-oligosaccharides, amino acids and peptides, and may provide a fermented drink with suitable sensory properties, that may mask the characteristic soy taste and decrease the non-digestible fructo-oligosaccharides (Pereira et al., 2009).

Kefir is obtained by the fermentation of milk with a mixed microbiota confined to a matrix of "kefir grains". Lactic acid bacteria (Lactobacilli, Lactococci, Leuconostoc), acetic acid bacteria and several genera of yeast are present in this mixed microflora, coexisting in a symbiotic association and are responsible for an acidic-alcoholic fermentation (Garrote et al., 2001). Kefir consumption has been associated to several health-promoting properties such as antimicrobial, antitumoral, immunological and hypocholesterolemic effects and is empirically used in many eastern European regions to treat different gastrointestinal disorders (Romanin et al., 2010).

Given that both kefir and soymilk are beneficial to human health, this study aimed to produce soymilk kefir and to investigate the effect of different percentages of soymilk on the lactobacilli cell viability to obtain an innovative product and with probiotic properties. We also aimed to assess the relationship between the physicochemical characteristics and the acceptability of fermented beverages.

\section{Materials and methods}

\subsection{Materials and preparation of the Soymilk Kefir}

The soymilk was prepared with lipoxygenase free soybean BRS257 donated by Cooproeste (Bahia State, Brazil). Soybeans were selected, washed and immersed in distilled water using 1:10 ratio (grains:water; w:v). The preparation was soaked for $24 \mathrm{~h}$, triturated and filtered to obtain the soymilk and the residue was discarded (adapted from Baú et al., 2013). The Kefir grains were obtained from the Health Science Center (Bahia State, Brazil), and propagated at $25^{\circ} \mathrm{C}$ for $20 \mathrm{~h}$ with twice- or thrice-weekly transfers in sterilized cow milk (50 g/L) and kept at $4{ }^{\circ} \mathrm{C}$. The sterilized soymilk containing $2 \%(\mathrm{w} / \mathrm{v})$ sucrose was added with $5 \%(\mathrm{w} / \mathrm{v})$ kefir grains and the samples were incubated at $25^{\circ} \mathrm{C}$ for $20 \mathrm{~h}$.

\subsection{Starter culture and elaboration of the soymilk Kefir-based functional beverages}

The strains Lactobacillus subspecie bulgaricus and Streptococcus thermophiles were obtained from lyophilized culture LA-NCFM (Chr. Hansen ${ }^{\circledR}$, São Paulo, Brazil). The inoculum was prepared the day before its use, reactivated in De Man Rogosa Sharpe - MRS broth (Sigma-Aldrich, Dorset, UK), and kept at $37^{\circ} \mathrm{C}$ for 16 hours. The functional beverages were prepared from soymilk Kefir added to sterilized integral cow milk and sucrose, according to the following ratios $(\mathrm{v} / \mathrm{v} / \mathrm{w}): 100: 0: 10\left(\mathrm{CMB}_{\text {Control }}\right), 90: 10: 7$ (SKB10), 80:20:6 (SKB20), 70:30:5 (SKB30), 60:40:4 (SKB40).
After the starter culture was inoculated $(1 \%, v / v)$, the beverages were dispensed into sterile jars and incubated at $37^{\circ} \mathrm{C}$ for $16 \mathrm{~h}$ until the fermentation process is complete $(4.5 \mathrm{pH})$. The total level of inoculum was about $7 \log _{10} \mathrm{CFU} \mathrm{mL} \mathrm{mL}^{-1}$ per treatment. The samples were packed in sterile glass containers and stored at $5{ }^{\circ} \mathrm{C}$ for further evaluation (titratable acidity and $\mathrm{pH}$ were immediately measured).

\subsection{Microbiological evaluation}

The microbiological evaluations of soymilk kefir-based beverages and control treatment were made for the most probable number (MPN) of coliforms at $35^{\circ} \mathrm{C}$ and at $45^{\circ} \mathrm{C} / \mathrm{mL}$, count of positive coagulase Staphylococcus in colony forming unit $\left(\mathrm{CFU} \mathrm{mL} \mathrm{m}^{-1}\right)$, detection of Salmonella sp. (presence or absence). Yeasts and molds were counted on potato dextrose agar (Difco, Detroit, Mich., U.S.A.) containing $100 \mathrm{mg} / \mathrm{mL}$ chlortetracycline after aerobic incubation at $25^{\circ} \mathrm{C}$ for 5 days, the results were expressed as logarithmic colony forming units per product milliliter $\left(\log _{10} \mathrm{CFU} \mathrm{mL} \mathrm{m}^{-1}\right)$ and lactobacilli cell viability $\left(\log _{10} \mathrm{CFU} \mathrm{mL} \mathrm{m}^{-1}\right)$ was determined by the standard plate method with Lactobacilli MRS medium (Sigma-Aldrich) after incubation at $37^{\circ} \mathrm{C}$ for $72 \mathrm{~h}$. All evaluations were performed in triplicate and according to the methodology described by American Public Health Association-APHA (Downes \& Ito, 2001).

\subsection{Sensory evaluation}

A ranked-preference test was conducted with 60 consumers (40 females and 20 males) that were verbally recruited from the pool of students and employees at the Federal University of Bahia Reconcave-UFRB, according to their interest, availability and habit of consumption of fermented beverages. Ethical clearance approval for this study was granted by the UFRB Ethics Committee (Process n. 31797114.056). For the test, $25 \mathrm{~mL}$ samples of each treatment were served at $8{ }^{\circ} \mathrm{C}$ in three-digit coded disposable cups, and were randomly presented to the panelists. The test was conducted in an individual booth, a well-lit environment, at day-light and mineral water was provided between consecutive samples for mouthrinsing. A standard five-point preference scale $(1=$ most preferred to $5=$ least preferred $)$ was used to evaluate the overall impression attribute (Meilgaard et al., 2007).

\subsection{Chemical and physicochemical evaluation}

The samples were characterized for moisture, total solids, proteins, lipids and ash content according to procedures recommended by the Association of Official Agricultural Chemists-AOAC (Association of Official Analytical Chemists, 2010), methods n. 92523, 99120, 90502 and 94546 , respectively. The total carbohydrates were calculated by difference and the caloric values were calculated using ATWATER coefficients, carbohydrates $=4.0 \mathrm{kcal} . \mathrm{g}^{-1}$, lipids $=9.0 \mathrm{kcal} . \mathrm{g}^{-1}$, proteins $=4.0 \mathrm{kcal} . \mathrm{g}^{-1}$ (Brasil, 2005). The $\mathrm{pH}$ was measured on a digital potentiometer (PG 1800 Gehaka, Brazil) properly calibrated with buffer solution for $\mathrm{pH} 4.0$ and 7.0; titratable acidity (TA) was determined by titration of $10 \mathrm{~g}$ of sample with $0.1-\mathrm{N} \mathrm{NaOH}$ solution to reach $\mathrm{pH}$ 8.1, expressed in $\mathrm{g}$ of lactic acid. $100 \mathrm{~g}^{-1}$. All analyses were performed in triplicate. 


\subsection{Shelf-life of peach-flavored soymilk Kefir-based functional beverage}

A peach-flavored soymilk kefir-based functional beverage (SKBP) was obtained from samples of the SKB30 treatment added with peach-pulp (4\%) and fructo-oligosaccharides-FOS $(2 \%)$. The shelf-life was determined by the increase or decrease of $\mathrm{pH}$ and lactobacilli viable cell count during cold storage at $5{ }^{\circ} \mathrm{C}$ for $7,14,21$ and 28 days. The acceptability was checked in a group of 126 consumers verbally recruited downtown of Santo Antonio de Jesus city (Bahia State, Brazil) using a 9-point structured hedonic scale ( $9=$ liked extremely to $1=$ disliked extremely) and the purchase intention by a 5 -point structured scale $(5=$ would certainly buy and $1=$ would certainly not buy) (Meilgaard et al., 2007). For the test, $25 \mathrm{~mL}$ samples were served at $8^{\circ} \mathrm{C}$ in three-digit coded disposable cups and were randomly to be presented to consumers. They also filled a form with information about age, gender and frequency of fermented dairy beverages consumption.

\subsection{Statistical analysis}

The experiment was carried out in an entirely randomized design, with three repetitions. The results of each parameter were expressed as mean ( \pm standard deviation). Significance $(P<0.05)$ was tested by one-way variance analysis (ANOVA) and Tukey's multiple comparison method was used to examine significant differences, using Statistical Analysis System-SAS software (Statistical Analysis System, 2015).

\section{Results and discussion}

\subsection{Microbiological evaluation}

The results of microbiological evaluation showed that the MPN $/ \mathrm{mL}$ of coliforms were less 3 , there was a concentration $<1 \times 10^{2} \mathrm{CFU} / \mathrm{mL}$ of positive coagulase Staphylococcus, research on Salmonella sp. indicated its absence in the samples examined (Table 1). These results prove that all samples were processed, handled and stored under healthy condition, were suitable for human consumption and in according to the microbiological standards required by the Brazilian legislation (Brasil, 2001).

The lactobacilli cell viability count showed significant difference $(P<0.05)$ among the treatments and ranged from 7.0 to $8.0 \log _{10} \mathrm{CFUmL}^{-1}$; yeasts and molds count was also significantly different $(P<0.05)$ and ranged from 4.3 to $5.6 \log _{10}$ CFUmL ${ }^{-1}$. A higher viable cell count (lactobacilli and yeast) was observed for treatments with higher soymilk Kefir percentage, indicating that part of the microbiota contained in the kefir grains was transferred to these beverages. All treatments presented viable cells above the minimum recommended for a probiotic product (6.0 $\left.\log _{10} \mathrm{CFUmL}^{-1}\right)$ at the time of consumption, based on a daily dose of $100 \mathrm{~mL}$ (Brasil, 2007), although are required specific tests to classify this beverage as probiotic.

Similar results were found in fermented soymilk with kefir grains, in a study on the effect of added glucose, lactose and sucrose on microbial growth (Liu \& Lin, 2000). These authors showed higher initial counts of lactic-acid bacteria and yeasts in soymilk than those found in cow milk drinks, with concentrations for lactic-acid bacteria of $7.0 \log _{10} \mathrm{CFUmL}^{-1}$ and $6.0 \log _{10} \mathrm{CFUmL}^{-1}$, and for yeasts of $5.8 \log _{10} \mathrm{CFUmL}^{-1}$ and $4.7 \log _{10} \mathrm{CFUmL}^{-1}$, respectively. According to the authors, the lactic-acid bacteria and yeasts from kefir grains grew well in samples with soymilk, meaning that these organisms can use the carbohydrates present in soymilk for growth, which are mainly sucrose, raffinose, and stachyose, whereas in cow milk it is lactose. On the other hand, soymilk kefir with $1 \%$ glucose had the highest yeast density $\left(6.4 \log _{10} \mathrm{CFUmL}^{-1}\right.$ ) after $32 \mathrm{~h}$ of fermentation. The authors concluded that the addition of $1 \%$ glucose greatly enhances growth of both lactic-acid bacteria and yeasts in soymilk.

Bergmann et al. (2010) quantified the microbial content of a sugary kefir sample from Brazil, and the microbial profile of kefir was different from other sources of grains despite the presence of similar microorganisms and others which have not been reported yet. Microbial analyses revealed the following bacteria and yeasts, respectively: Leuconostoc ssp., Lactobacillus lactis cremoris, Chyseomonas luteola, Acetobacter, Saccharomyces cerevisiae, Candida colliculosa, Toruspola delbruechii, Candida inconspicua, Candida magnoliae, Kloekera sp., Candida famata, Kluyveromices lactis, Kluyveromices marxianus, and Candida kefir.

Lin et al. (1999) identified and characterized yeasts isolated of kefir grains from Taiwan. This study showed that Kefir grains contain: Saccharomyces cerevisiae and Pichia fermentans (non-lactose-fermenting) as well as Kluyveromyces lactis, Kluyveromyces marxianus, Torula kefir (lactose-fermenting). The authors concluded that yeasts are important in kefir

Table 1. Results of microbiological evaluation for soymilk kefir-based functional beverages and control treatment.

\begin{tabular}{|c|c|c|c|c|c|c|c|}
\hline \multirow{2}{*}{ Microorganisms } & \multicolumn{7}{|c|}{ Treatments } \\
\hline & $\mathrm{CMB}_{\text {Control }}^{1}$ & $\mathrm{SKB} 10^{2}$ & SKB20 & SKB30 & SKB40 & $\mathrm{SKBP}^{3}$ & $\mathrm{SMD}^{*}$ \\
\hline Coliforms at $45^{\circ} \mathrm{C}\left(\mathrm{MPN} \mathrm{mL}^{-1}\right)$ & $<3.0^{* *}$ & $<3.0$ & $<3.0$ & $<3.0$ & $<3.0$ & $<3.0$ & - \\
\hline Coliforms at $35^{\circ} \mathrm{C}\left(\mathrm{MPN} \mathrm{mL}^{-1}\right)$ & $<3.0$ & $<3.0$ & $<3.0$ & $<3.0$ & $<3.0$ & $<3.0$ & - \\
\hline Pos. Coag. Staphylococcus (CFU mL $\left.\mathrm{m}^{-1}\right)$ & $<1 \times 10^{2}$ & $<1 \times 10^{2}$ & $<1 \times 10^{2}$ & $<1 \times 10^{2}$ & $<1 \times 10^{2}$ & $<1 \times 10^{2}$ & - \\
\hline Salmonella sp. (Presence) & A & A & A & A & A & A & - \\
\hline Yeasts and molds $\left(\log _{10} \mathrm{CFU} \mathrm{mL} \mathrm{m}^{-1}\right)$ & $0.0 \mathrm{a}$ & $4.3 \mathrm{~b}$ & $5.1 \mathrm{c}$ & $5.4 \mathrm{~d}$ & $5.6 \mathrm{~d}$ & $5.4 \mathrm{~d}$ & 0.2 \\
\hline
\end{tabular}

${ }^{1} \mathrm{CMB}_{\text {Control }}=$ Cow milk-based beverage (without soymilk kefir); ${ }^{2}$ SKB10, SKB20, SKB30, SKB40 = Soymilk kefir-based functional beverages with different percents of soymilk kefir;

${ }^{3} \mathrm{SKBP}=$ Functional beverage added of peach-flavor; ${ }^{\star} \mathrm{SMD}=$ Signicant Minimum Difference. Means with same letter (same line) do not differ significantly by Tukey's test $(P<0.05)$;

${ }^{* *}$ Mean $(\mathrm{n}=3) ; \mathrm{A}=$ absence. 
fermentation because the production of ethanol and carbon dioxide confers the product's unique taste.

Inoguchi et al. (2012) studied the effects of non-fermented soybean milk (NFSM) and fermented soybean milk (FSM) intake on the faecal microbiota and metabolic activities in healthy volunteers. The authors showed that during the dietary administration of FSM, the number of bifidobacteria and lactobacilli in faeces increased $(p<0.05)$, clostridia decreased $(p<0.05)$ and also the concentration of faecal sulphide decreased $(p<0.01)$. These results indicate that the consumption of FSM is related to the improvement of the intestinal environment.

\subsection{Sensory evaluation}

The SKB40 treatment was significantly least preferred by consumers (Tukey's test, $P<0.05$ ), probably due to the higher soymilk ratio (40\%) and lower sucrose content (4\%). Products with higher percent of soy are often less accepted by consumers due to its characteristic flavor, identified as "raw bean" (Viana et al., 2011). The others treatments $\left(\mathrm{CMB}_{\text {Control }}\right.$ SKB10, SKB20 and SKB30) showed no significant difference, i.e. soymilk ratios of up to $30 \%$ were equally preferred by consumers. Similar tendency was found in probiotic beverages developed by Kempka et al. (2008), whose ideal formulation was soymilk (30.1\%), milk serum (33.3\%) and cow milk (36.6\%) for good sensory acceptability and higher viable cell count.

During the fermentation process, organic acids (lactic and acetic) are the main products, of which acetic acid is highly associated with the unpleasant vinegar flavor. The presence of lactic acid in fermented beverages is more desirable as it has been described to warrant a proper flavor and to encompass a 'mild sour' flavor (Stroehle et al., 2006). Kefir grains contain a complex flora of lactic-acid bacteria, yeasts, and sometimes acetic-acid bacteria, that coexist in a symbiotic association and are responsible for acidic-alcoholic fermentation (Lin et al., 1999). Park et al. (2005) found that the sensory quality of yogurt-like products prepared from a combination of skim milk and soymilk (100:0, 75:25, 50:50, 25:75, 0:100) and fermented by a mixed culture (Streptococcus thermophilus, Lactobacillus acidophilus, Lactobacillus bulgaricus and Bifidobacterium longum) had higher preference compared with that produced from a single culture (Streptococcus thermophilus).

\subsection{Chemical and physicochemical evaluation}

The chemical and physicochemical results showed significant differences $(P<0.05)$ among the studied treatments (Table 2). The $\mathrm{pH}$ and titratable acidity (TA) values of fermented beverages after $16 \mathrm{~h}$ of fermentation were in the range of 4.4 to 4.6 and $0.5 \%$ to $0.7 \%$, respectively. These parameters showed a similar trend, no effect of the soymilk ratio. However, the SKB40 treatment differed significantly $(P<0.05)$ from the control treatment in TA and $\mathrm{pH}$ values. These differences are probably due to distinct sugar ratios in the treatments (higher sucrose percent for control). These nutrients probably stimulated the starter culture that produced organic acids, lowering $\mathrm{pH}$ and increasing TA of the control treatment. The TA values are comparable to those reported by Park et al. (2005) in dairy-based probiotic products (0.5-0.7\%), and significantly higher than those reported by Wang et al. (2003) in soy-based fermented products $(0.18-0.19 \%)$, with no added sugar. Similar trend was showed in products fermented with kefir grains (Liu \& Lin, 2000), the authors found a higher value of TA $(1.6 \pm 0.03 \%)$ for cow milk kefir-based beverage than those reported for soymilk kefir-based beverage $(0.9 \pm 0.1 \%)$ without added carbohydrate. Rocha et al. (2014) developed a functional probiotic labneh (concentrated yogurt) using kefir as a fermenting agent, after 24 hours of fermentation showed maximum TA values of $0.8 \%$ and $0.9 \%$ lactic acid for whole and skimmed kefir, respectively.

The $\mathrm{pH}$ values are similar to those reported by Park et al. (2005) in probiotic dairy and soy based products ( 4.3 to 4.5 ) and higher than those observed by Salmerón et al. (2015) in other fermented cereals ( 3.5 to 4.0 ). In fermented beverages, $\mathrm{pH}$ is relevant for the microbiological stability, to avoid food-borne pathogens and acid-sensitive microorganisms, and may be directly correlated with the products taste (Farnworth et al., 2007). Some factors can modify the $\mathrm{pH}$ value of fermented products, such as use of different starter cultures, addition of different substrate ratios, milk composition, processing conditions and storage temperature (Chauhan et al., 2007).

A positive effect of the soymilk ratios was observed on protein content (PC), samples with higher soymilk percent presented higher $\mathrm{PC}$, and there was a significant difference among the treatments. The nutritional value of soy protein is

Table 2. Chemical and physicochemical results of the soymilk kefir-based functional beverages and control treatment.

\begin{tabular}{|c|c|c|c|c|c|c|c|}
\hline \multirow{2}{*}{ Evaluations } & \multicolumn{7}{|c|}{ Treatments } \\
\hline & $\mathrm{CMB}_{\mathrm{Control}} 1$ & SKB10 ${ }^{2}$ & SKB20 & SKB30 & SKB40 & SKBP $^{3}$ & $\mathrm{SMD}^{*}$ \\
\hline $\mathrm{pH}$ & $4.4 \pm 0.1 \mathrm{a}$ & $4.5 \pm 0.1 \mathrm{ab}$ & $4.5 \pm 0.1 \mathrm{ab}$ & $4.5 \pm 0.1 \mathrm{ab}$ & $4.6 \pm 0.1 \mathrm{~b}$ & $4.6 \pm 0.1 \mathrm{~b}$ & 0.2 \\
\hline Titratable Acidity (glactic ac. $100 \mathrm{~g}^{-1}$ ) & $0.7 \pm 0.0 \mathrm{c}$ & $0.6 \pm 0.0 \mathrm{~b}$ & $0.6 \pm 0.0 \mathrm{~b}$ & $0.6 \pm 0.0 \mathrm{~b}$ & $0.5 \pm 0.0 \mathrm{a}$ & $0.5 \pm 0.0 \mathrm{a}$ & 0.1 \\
\hline Protein $\left(\mathrm{g} 100 \mathrm{~g}^{-1}\right)$ & $2.9 \pm 0.5 \mathrm{a}$ & $3.3 \pm 0.2 b$ & $3.5 \pm 0.4 \mathrm{~b}$ & $3.5 \pm 0.5 \mathrm{~b}$ & $3.9 \pm 0.0 \mathrm{c}$ & $3.5 \pm 0.0 \mathrm{~b}$ & 0.4 \\
\hline Lipid $\left(\mathrm{g} 100 \mathrm{~g}^{-1}\right)$ & $2.5 \pm 0.1 \mathrm{e}$ & $2.3 \pm 0.1 \mathrm{~d}$ & $2.0 \pm 0.1 \mathrm{c}$ & $1.8 \pm 0.1 \mathrm{~b}$ & $1.6 \pm 0.1 \mathrm{a}$ & $1.8 \pm 0.1 \mathrm{~b}$ & 0.1 \\
\hline $\operatorname{Ash}\left(\mathrm{g} \mathrm{100g}^{-1}\right)$ & $0.7 \pm 0.1 \mathrm{~d}$ & $0.6 \pm 0.1 \mathrm{c}$ & $0.5 \pm 0.1 \mathrm{~b}$ & $0.5 \pm 0.1 \mathrm{~b}$ & $0.5 \pm 0.1 \mathrm{~b}$ & $0.4 \pm 0.1 \mathrm{a}$ & 0.1 \\
\hline Total solid $\left({\left.\mathrm{g} 100 \mathrm{~g}^{-1}\right)}^{-1}\right.$ & $20.0 \pm 0.2 \mathrm{e}$ & $14.7 \pm 0.1 \mathrm{c}$ & $14.7 \pm 0.1 \mathrm{c}$ & $14.0 \pm 0.2 \mathrm{~b}$ & $13.6 \pm 0.2 \mathrm{a}$ & $15.8 \pm 0.2 \mathrm{~d}$ & 0.1 \\
\hline Moisture content $\left({\left.\mathrm{g} 100 \mathrm{~g}^{-1}\right)}\right.$ & $80.0 \pm 0.2 \mathrm{a}$ & $85.3 \pm 0.1 \mathrm{c}$ & $85.4 \pm 0.1 \mathrm{c}$ & $86.0 \pm 0.2 \mathrm{~d}$ & $86.4 \pm 0.2 \mathrm{~d}$ & $84.2 \pm 0.2 \mathrm{~b}$ & 0.7 \\
\hline Total carbohydrate & $13.9 \pm 0.2 \mathrm{~d}$ & $8.5 \pm 0.2 b$ & $8.6 \pm 0.4 b$ & $8.2 \pm 0.1 \mathrm{~b}$ & $7.6 \pm 0.0 \mathrm{a}$ & $10.1 \pm 0.1 \mathrm{c}$ & 0.6 \\
\hline Total caloric value $^{4}\left(\mathrm{Kcal}_{100 \mathrm{~g}^{-1}}\right)$ & $89.7 \pm 0.7 \mathrm{~d}$ & $67.9 \pm 0.2 \mathrm{~b}$ & $66.4 \pm 0.2 b$ & $63.0 \pm 0.1 \mathrm{a}$ & $60.4 \pm 0.2 \mathrm{a}$ & $70.6 \pm 0.3 \mathrm{c}$ & 2.7 \\
\hline
\end{tabular}

${ }^{1} \mathrm{CMB}_{\text {Control }}=$ Cow milk-based beverage (without soymilk kefir); ${ }^{2}$ SKB10, SKB20, SKB30, SKB40 = Soymilk kefir-based functional beverages with different percents of soymilk kefir;

${ }^{3} \mathrm{SKBP}=$ Functional beverage added of peach-flavor; ${ }^{4}$ Calculated using ATWATER coefficients: Protein $=4 \mathrm{kcal} . \mathrm{g}^{-1}$, Lipids $=9 \mathrm{kcal} . \mathrm{g}^{-1}$, Carbohydrates $=4 \mathrm{kcal} . \mathrm{g}^{-1} ;{ }^{*} \mathrm{SMD}=$ Significant

Minimum Difference. Means with same letter (same line) do not differ significantly by Tukey's test $(P<0.05)$ 
well known and it can be added as an alternative ingredient in fermented beverages; however, products with higher soy ratios are often less accepted by consumers due to its characteristic flavor, identified as "raw bean" (Jaekel et al., 2010). Moreover, amino acids and peptides tend to produce a taste stimulus associated with bitterness. Such molecules reach the taste receptors through the saliva and mucus that cover them. The bitter taste has been described as aversive to the palate. Despite this, humans can tolerate a mild bitter taste or even find it attractive (Bufe \& Meyerhof, 2006). Possibly, this fact could explain lower acceptance score found to the SKB40 treatment. Higher PC was reported in fermented beverages using other substrates as malt (55.2-183.5 mg/L), barley (17.6-53.8) and oat (16.2-30.6 mg/L) (Salmerón et al., 2015). Lower PC was found in others studies with soymilk-based fermented beverages that ranged from $2.2 \%$ to $2.6 \%$ (Costa et al., 2013).

Conversely, a negative effect of the soymilk ratio was observed on lipid, ash, total solid and carbohydrate content, with lower values for higher soymilk ratios. There was a significant difference among treatments, and samples with soymilk presented lower values compared to control treatment. Consumers are changing their consumption habits for healthier food with lower lipid content (LC), a known characteristic of soybean-based products (Tsuchiya et al., 2006). Similar results were found in soymilk-based fermented beverages $(1.8 \%$ to $2.0 \%$ ) by Costa et al. (2013). Magalhães et al. (2011) studied the chemical composition of Brazilian kefir beverage and showed that during $24 \mathrm{~h}$ of fermentation, the protein content increased, while lipid and lactose content decreased.

Integral cow milk is known to present higher ash content (AC), due to the presence of calcium and others minerals, when compared to soymilk. Similar tendency were found in dairy probiotics with $50 \%$ and $40 \%$ whey, being $0.5 \%$ and $0.6 \%$ AC, respectively (Thamer \& Penna, 2006) and in fermented soymilk-based beverages, with $0.5 \%$ to $0.6 \% \mathrm{AC}$ (Costa et al. 2013). Similarly, higher total solid (TS) content for control treatment is due mainly to lipids and carbohydrates contents from integral cow milk. Similar results were found in fermented soymilk-based beverages ranging from $15.6 \%$ to $20.0 \%$ TS (Costa et al., 2013). Total carbohydrate content (TC) was also much lower in soymilk treatments than in control, due to the contribution of lactose and total solids content from integral cow milk. The caloric value (CV) followed the same tendency, with lower values for soymilk treatments. Similar results were found in fermented dairy beverages (63.9 to $79.3 \mathrm{Kcal}^{100 \mathrm{~g}^{-1}}$ ), with higher CV for treatments with higher cow milk ratio and lower CV for samples with higher whey content (Cunha et al., 2009).

The peach-flavored treatment (SKBP) showed similar results, lower lipid, ash, total solid content when compared to control; however, it presented higher carbohydrate and caloric values when compared to soymilk treatments, due to polysaccharides and single sugars present in the peach pulp. Similar results were found in soymilk-based drinks added of peach pulp, with protein content of $2.2 \%$ and caloric value of $69.7 \mathrm{Kcal}^{100 \mathrm{~g}^{-1}}$ (Rodrigues \& Moretti, 2008).

\subsection{Shelf-life of peach-flavored Soymilk Kefir-based functional beverage}

Figure 1 shows that viable cells count ranged from 7.3 to $7.0 \log _{10} \mathrm{CFU} \mathrm{mL} \mathrm{mL}^{-1}$ and the $\mathrm{pH}$ value decreased slightly from 4.5 on the $7^{\text {th }}$ day to 4.3 on the $28^{\text {th }}$ day. The good quality of soymilk kefir-based functional beverage added of peach flavor (SKBP) during cold storage defined the shelf life of 28 days (high viable cells count and appropriate $\mathrm{pH}$ value). Similar results were found in goat milk-based probiotic yogurts with $\mathrm{pH}$ ranging from 4.4 to 4.5 (Güler-Akin \& Akin, 2007). A decrease in $\mathrm{pH}$ (from 4.9 to 4.3 ) on the $19^{\text {th }}$ day of cold storage was also observed in probiotic beverages added of peach-flavor by Kempka et al. (2008), leading the authors to conclude that the beverages stability was directly related to $\mathrm{pH}$ value. The lactic acid bacteria (LAB) viability during cold storage is fundamental for the production of organic acids (mainly lactic acid) and $\mathrm{pH}$ value, which determine microbiological stability and avoid food-borne pathogens, allowing longer shelf-life to fermented products than to traditional products and promoting the probiotic properties (Tripathi \& Giri, 2014).

Figure 2 shows the consumption frequency distribution for the SKBP by consumers in Santo Antonio de Jesus city, Bahia State, Brazil. The group consisted of 126 individuals, aging from

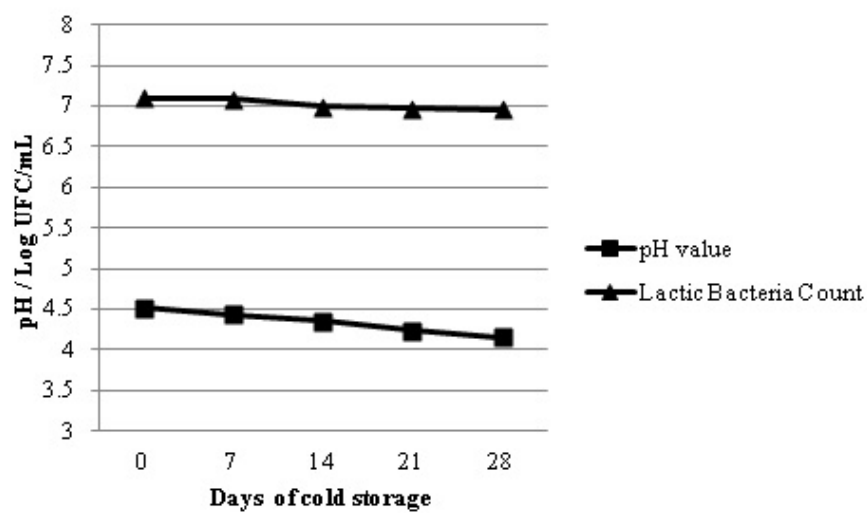

Figure 1. Averages of viable cells count and $\mathrm{pH}$ values for the soymilk kefir-based functional beverage with peach-flavor during 28 days of cold storage.

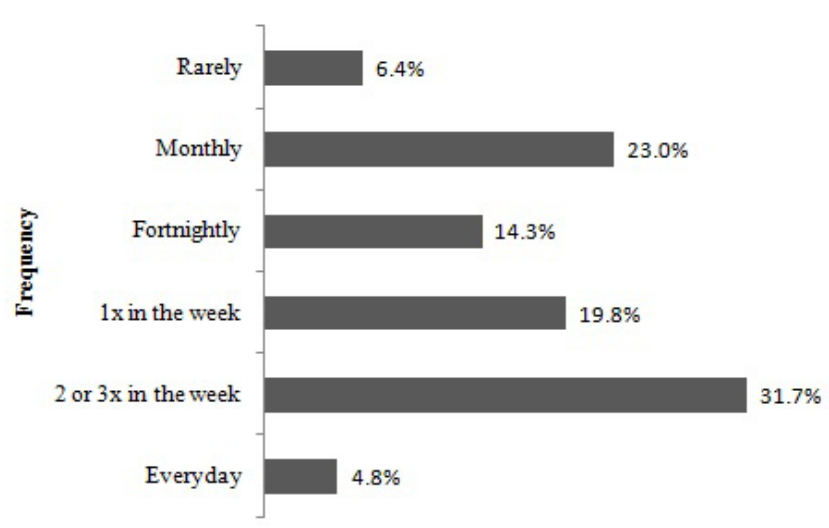

Figure 2. Consumption frequency distribution for probiotic beverages with consumers in Santo Antonio de Jesus city, Bahia State, Brazil. 
30 to 39 years old, composed of $52.0 \%$ males and $48.0 \%$ females. Regarding habits of probiotic beverages consumption, $51.5 \%$ of the consumers buy these products at least once a week, and only $4.8 \%$ daily. According to the Research of Familiar Budget carried out in Brazil (2008 - 2009) the consumption of yogurts and dairy drinks decreases with the increase of age in the population (Instituto Brasileiro de Geografia e Estatística, 2011). According to these data, teenagers are the main consumers of dairy drinks, followed by young adults and older people.

Figure $3 \mathrm{~A}$ presents the frequency distribution of the acceptability test for the SKBP obtained with consumers in Santo Antonio de Jesus city, Bahia State, Brazil. Results showed that the SKBP obtained $94.5 \%$ of positive acceptance $(6,7,8$ and 9 scores), $4 \%$ of rejection ( 3 and 4 scores) and only $1.5 \%$ of indifference zone (5 score) for overall impression attribute. The product presented adequate sensory characteristics and potential to be marketed. Figure $3 \mathrm{~B}$ presents the frequency distribution of the purchase intention test for the SKBP by consumers in Santo Antonio de Jesus city, Bahia State, Brazil. Results showed that $83.4 \%$ of consumers presented positive purchase intention (4 and 5 scores) if the product was available in the market, confirming its good acceptability. The negative intention ( 1 and 2 scores) reached $3.2 \%$ and $13.5 \%$ of consumers were not sure.
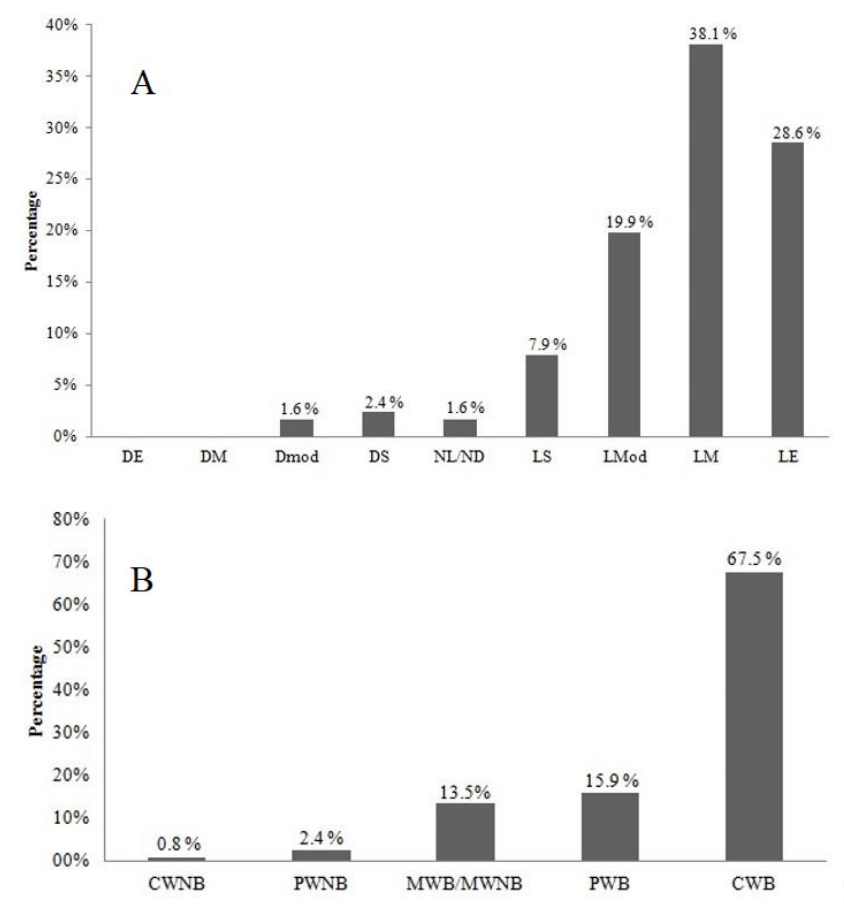

Figure 3. Frequency distribution for scores obtained for acceptability (A) and purchase intention (B) test of soymilk kefir-based functional beverage added of peach-flavor by consumers in Santo Antonio de Jesus city, Bahia State, Brazil. DE = Disliked Extremely; DM = Disliked Much; DMod = Disliked Moderately; DS = Disliked Slightly; NL/ND = Neither Liked/Nor Disliked; LS = Liked Slightly; LMod = Liked Moderately; LM = Liked Much; LE = Liked Extremely; CWNB = Certainly Would Not Buy; PWNB = Probably Would Not Buy; MWB/MWNB = Maybe Would Buy/Maybe Would Not Buy; PWB = Probably Would Buy; CWB $=$ Certainly Would Buy.
Similar results were found for acceptability of soymilk-based beverages prepared from different soybean cultivars, products from cultivar without lipoxygenase enzyme reached higher acceptance (Silva et al., 2007). These authors observed that the sugar content was the most important ingredient to increase the acceptability of soymilk-based drinks, when compared to fruit pulp content. Soymilk-based beverages with strawberry pulp and sucrose also showed higher acceptability (6.5 score) for higher sucrose content (15\%), due to the change in the characteristic soybean taste and unpleasant flavor (Branco et al., 2007). Studies on the consumer attitudes regarding probiotics products indicate an increase in the interest for functional foods that favors health benefits. However, there is a consensus about the lack of knowledge about the functionality and health benefits of these foods among the population, regardless of gender, age, educational and economic status (Siró et al., 2008).

\section{Conclusions}

Samples with higher soymilk Kefir percentage presented higher lactobacilli cell count (7.0 to $8.0 \log _{10} \mathrm{CFUmL}^{-1}$ ). Conversely was found lower lipid, ash, total solid, carbohydrate content, caloric value and titratable acidity for the treatments with higher soymilk Kefir percentage. The soymilk kefir-based beverages showed equal preference up to $30 \%$ of soymilk addition. The peach-flavored beverage presented appropriate $\mathrm{pH}$ (4.3) and high viable cells count (7.0 $\left.\log _{10} \mathrm{CFUmL}^{-1}\right)$ until the $28^{\text {th }}$ day of cold storage, showed high acceptability (94.5\%) and positive purchase intention $(83.4 \%)$ by consumers, indicating great marketing potential.

\section{References}

Al-Sheraji, S. H., Ismail, A., Manap, M. Y., Mustafa, S., Yusof, R. M., \& Hassan, F. A. (2013). Prebiotics as functional foods: A review. Journal of Functional Foods, 5(1), 1542-1553. http://dx.doi.org/10.1016/j. jff.2013.08.009.

Association of Official Analytical Chemists - AOAC. (2010). Official methods of analysis of AOAC International (18th ed., Vol. I, II). Washington: AOAC.

Baú, T. R., Garcia, S., \& Ida, E. I. (2013). Optimization of a fermented soy product formulation with a kefir culture and fiber using a simplexcentroid mixture design. International Journal of Food Sciences and Nutrition, 64(8), 929-935. PMid:23876105. http://dx.doi.org/10.31 09/09637486.2013.816935.

Bergmann, R. S. O., Pereira, M. A., Veiga, S. M. O. M., Schneedorf, J. M., Oliveira, N. M. S., \& Fiorini, J. E. (2010). Microbial profile of a kefir sample preparations - grains in natura and lyophilized and fermented suspension. Food Science and Technology, 30(4), 10221026. http://dx.doi.org/10.1590/S0101-20612010000400029.

Branco, I. G., Teixeira, A. M., Rigo, M., Bezerra, J. R. M. V., Coutinho, M. R., Argandoña, E. J. S., \& Bastos, R. G. (2007). Sensory acceptability of the soymilk-based beverage containing strawberry pulp and sucrose. Revista Ciências Exatas Naturais, 9(1), 129-141.

Brasil. Ministério da Saúde. Agência Nacional de Vigilância Sanitária - ANVISA. (2001). Approves the regulation about microbiological standards for foods and derivatives, Attachments I and II (Resolution $\mathrm{n}^{\circ} 12$ of $2^{\text {nd }}$ january 2001). Diário Oficial [da] República Federativa do Brasil. 
Brasil. Ministério da Saúde. Agência Nacional de Vigilância Sanitária ANVISA. (2005). Approves the technical regulation about nutritional labeling of packaged foods (Resolution $\mathrm{n}^{\mathrm{o}} 360$ of $26^{\text {th }}$ december 2005). Diário Oficial [da] República Federativa do Brasil.

Brasil. Ministério da Saúde. Agência Nacional de Vigilância Sanitária - ANVISA. (2007). Foods with claims and functional properties or health, novel foods/ingredients, bioactive substances and. Updated in August 2007. IX -List of approved claims for functional properties. Brasília: ANVISA. Retrieved from http://anvisa.gov.br/alimentos/ comissoes/ tecno_lista_alega.htm

Bufe, B., \& Meyerhof, W. (2006). The human perception of taste compounds. In A. Voilley \& P. Etiévant (Eds.), Flavour in food. Abington: Woodhead Publishing Limited.

Chauhan, K., Trivedi, U., \& Patel, K. (2007). Statistical screening of medium components by Plackett-Burman design of lactic acid production by Lactobacillus sp. KCP01 using date juice. Bioresearch Technology, 98(1), 98-103. PMid:16386897. http://dx.doi.org/10.1016/j. biortech.2005.11.017.

Costa, M. G. M., Fonteles, T. V., De Jesus, A. L. T., \& Rodrigues, S. (2013). Sonicated pineapple juice as substrate for $L$. casei cultivation for probiotic beverage development: process optimisation and product stability. Food Chemistry, 139(1-4), 261-266. PMid:23561104. http:// dx.doi.org/10.1016/j.foodchem.2013.01.059.

Cunha, T. M., Ilham, E. C., Amboni, R. D. M. C., Barreto, P. L. M., Castro, F., \& Prudêncio, E. (2009). The influence of whey and probiotic bacteria on the properties of fermented lactic beverages. Brazilian Journal of Food Technology, 12(1), 23-33. http://dx.doi. org/10.4260/BJFT2009200800004.

Downes, F. P., \& Ito, K. (2001). Compendium of methods for the microbiological examination of foods (4th ed.). Washington: APHA. $1160 \mathrm{p}$.

Falk, M. (2004). The impact of regulation on the information about the health promotion properties of functional foods in the USA. Journal of Food Science, 69(1), 143-149.

Farnworth, E. R., Mainville, I., Desjardins, M. P., Gardner, N., Fliss, I., \& Champagne, C. (2007). Growth of probiotic bacteria and bifidobacteria in a soy yogurt formulation. International Journal of Food Microbiology, 116(1), 174-181. PMid:17292991. http://dx.doi. org/10.1016/j.ijfoodmicro.2006.12.015.

Garrote, G. L., Abraham, A. G., \& De Antoni, G. L. (2001). Chemical and microbiological characterization of kefir grains. The Journal of Dairy Research, 68(4), 639-652. PMid:11928960.

Granato, D., Branco, G. F., Cruz, A. G., Faria, J. A. F., \& Nazzaro, F. (2010). Functional foods and nondairy probiotic food development: trends, concepts, and products. Journal of Food Science, 9(1), 292-302.

Güler-Akin, M. B., \& Akin, M. S. (2007). Effects of cysteine and different incubation temperatures on the microflora, chemical composition and sensory characteristics of bio-yogurt made from goat's milk. Food Chemistry, 100(1), 788-793. http://dx.doi.org/10.1016/j. foodchem.2005.10.038.

Inoguchi, S., Ohashi, Y., Narai-Kanayama, A., Aso, K., Nakagaki, T., \& Fujisawa, T. (2012). Effects of non-fermented and fermented soybean milk intake on faecal microbiota and faecal metabolites in humans. International Journal of Food Sciences and Nutrition, 63(4), 402-410. PMid:22040525. http://dx.doi.org/10.3109/09637486.2011.630992.

Instituto Brasileiro de Geografia e Estatística - IBGE. (2011). Research of Family Budget 2008-2009. Retrieved from http://www.ibge.org.br/

Jaekel, L. Z., Rodrigues, R. S., \& Silva, A. P. (2010). Physicochemical and sensorial evaluation of beverages with different proportions of soy and rice extracts. Food Science and Technology, 30(2), 342-348. http://dx.doi.org/10.1590/S0101-20612010000200009.

Kempka, A. P., Krüger, R. L., Valduga, E., Di Luccio, M., Treichel, H., Cansian, R., \& Oliveira, D. (2008). Formulation of a peach-flavored dairy drink using alternative substrates and probiotic culture. Food Science and Technology, 28(Suppl.), 170-177. http://dx.doi. org/10.1590/S0101-20612008000500027.

Lin, C. W., Chen, H. L., \& Liu, J. R. (1999). Identification and characterisation of lactic acid bacteria and yeasts isolated from kefir grains in Taiwan. Australian Journal of Dairy Technology, 54(1), 14-18. http://dx.doi.org/10.1021/jf048934k.

Liu, J. R., \& Lin, C. W. (2000). Production of kefir from soymilk with or without added glucose, lactose or sucrose. Journal of Food Science, 65(1), 716-719. http://dx.doi.org/10.1111/j.1365-2621.2000.tb16078.x.

Magalhães, K. T., Pereira, G. V. M., Campos, C. R., Dragone, G., \& Schwan, R. F. (2011). Brazilian Kefir: structure, microbial communities and chemical composition. Brazilian Journal of Microbiology, 42(2), 693-702. PMid:24031681. http://dx.doi.org/10.1590/S151783822011000200034

Meilgaard, M., Civille, G.V., \& Carr, B.T. (2007). Sensory evaluation techniques (388 p.). Boca Raton: CRC Press.

Park, D. J., Oh, S., Ku, K. H., Mok, C., Kim, S. H., \& Imm, J. Y. (2005). Characteristics of yogurt-like products prepared from the combination of skim milk and soymilk containing saccharified-rice solution. International Journal of Food Sciences and Nutrition, 56(1), 23-34. PMid:16019312. http://dx.doi.org/10.1080/09637480500082181.

Pereira, M. O., Bampi, M., Rodrigues, F. T., Santa, O. R. D., Santa, H. S. D., \& Rigo, M. (2009). Elaboration of soymilk-based probiotic beverage with fruit taste. Journal Agricultural Environment Science, 5(1), 475-487.

Research and Markets. (2017). Functional foods market assessment 2016. Retrieved from http://www.researchandmarkets.com/reports

Rocha, D. M. U. P., Martins, J. F. L., Santos, T. S. S., \& Moreira, A. V. B. (2014). Labneh with probiotic properties produced from kefir: development and sensory evaluation. Food Science and Technology, 34(4), 694-700. http://dx.doi.org/10.1590/1678-457x.6394.

Rodrigues, R. D. S., \& Moretti, R. H. (2008). Physico-chemistry characterization of protein drink elaborated with soymilk and peach pulp. Boletim CEPPA, 26(1), 101-110.

Romanin, D., Serradell, M., González Maciel, D., Lausada, N., Garrote, G. L., \& Umbo, M. (2010). Down-regulation of intestinal epithelial innate response by probiotic yeasts isolated from kefir. International Journal of Food Microbiology, 140(2-3), 102-108. PMid:20471126. http://dx.doi.org/10.1016/j.ijfoodmicro.2010.04.014.

Saad, N., Delattre, C., Urdaci, M., Schmitter, J. M., \& Bressollier, P. (2013). An overview of the last advances in probiotic and prebiotic field. Lebensmittel-Wissenschaft + Technologie, 50(1), 1-16. http:// dx.doi.org/10.1016/j.lwt.2012.05.014.

Salmerón, I., Thomas, K., \& Pandiella, S. S. (2015). Effect of potentially probiotic lactic acid bacteria on the physicochemical composition and acceptance of fermented cereal beverages. Journal of Functional Foods, 15(1), 106-115. http://dx.doi.org/10.1016/j.jff.2015.03.012.

Silva, J. B., Carrão-Panizzi, M. C., \& Prudêncio, S. H. (2009). Chemical and physical composition of grain-type and food-type soybean for food processing. Pesquisa Agropecuária Brasileira, 44(1), 777-784. http://dx.doi.org/10.1590/S0100-204X2009000700019.

Silva, J. B., Prudêncio, S. H., Felberg, I., Deliza, R., \& Carrão-Panizzi, M. C. (2007). Acceptability of beverages prepared from different soybean extracts. Pesquisa Agropecuária Brasileira, 42(12), 1779-1784. http://dx.doi.org/10.1590/S0100-204X2007001200016. 
Siró, I., Kápolna, E., Kápolna, B., \& Lugasi, A. (2008). Functional food, product development, marketing and consumer acceptance: a review. Appetite, 51(3), 456-467. PMid:18582508. http://dx.doi. org/10.1016/j.appet.2008.05.060.

Sloan, E. (2012). Top ten food trends. Journal of Food Technology, 67(1), 24-40.

Statistical Analysis System - SAS. (2015). SAS/STAT user's procedures guide. Release 6.0. Cary: SAS Institute.

Stroehle, L., Zweytick, G., \& Berghofer, E. (2006). Sauerkraut fermentation with L(+)-lactic acid producing bacteria. Ernaehrung, 30(1), 293-303.

Thamer, K. G., \& Penna, A. L. B. (2006). Characterization of functional dairy beverages fermented by probiotics and with the addition of prebiotics. Food Science and Technology, 26(3), 589-595. http:// dx.doi.org/10.1590/S0101-20612006000300017.
Tripathi, M. K., \& Giri, S. K. (2014). Probiotic functional foods: survival of probiotics during processing and storage. Journal of Functional Foods, 9(1), 225-241. http://dx.doi.org/10.1016/j.jff.2014.04.030.

Tsuchiya, A., Almiron-Roig, E., Lluch, A., Guyonnet, D., \& Drewnowski, A. (2006). Higher satiety ratings following yogurt consumption relative to fruit drink or dairy fruit drink. Journal of the American Dietetic Association, 106(1), 550-557. PMid:16567151. http://dx.doi. org/10.1016/j.jada.2006.01.004.

Viana, J. V., Cruz, A. G., Zoellner, S. S., Silva, R., \& Batista, A. L. D. (2011). Probiotic foods: consumer perception and attitudes. International Journal of Food Science \& Technology, 43(1), 1577-1580.

Wang, Y. C., Yu, R. C., Yang, H. Y., \& Chou, C. C. (2003). Sugar and acid contents in soymilk fermented with lactic acid bacteria alone or simultaneously with bifidobacteria. Food Microbiology, 20(3), 333-338. http://dx.doi.org/10.1016/S0740-0020(02)00125-9. 